\title{
Phytomicrobiome Studies for Combating the Abiotic Stress
}

\author{
Shefali 1(D), Mahipal Singh Sankhla $^{2, *}$ (D), Rajeev Kumar ${ }^{3}$ (D), Swaroop S. Sonone 4 (D) \\ 1 Department of Zoology, DPG Degree College, Gurugram, Haryana; shefaligulliya@ gmail.com (S); \\ 2 Department of Forensic Science, School of Basic and Applied Sciences, Galgotias University, Greater Noida; \\ mahipa14n6@gmail.com (M.S.S.); \\ 3 Department of Forensic Science, School of Basic and Applied Sciences, Galgotias University, Greater Noida; \\ rajeev4n6@gmail.com (R.K.); \\ 4 Student of M.Sc. Forensic Science, Government Institute of Forensic Science, Aurangabad, Maharashtra; \\ sononeswap4@gmail.com (S.S.S.); \\ * Correspondence: mahipal4n6@gmail.com;
}

Received: 27.09.2020; Revised: 25.10.2020; Accepted: 27.10.2020; Published: 31.10.2020

\begin{abstract}
Agricultural productivity is limited by the various factors of which stresses are the principal ones. The reactive oxygen species (ROS) production in different cell sections is done by protracted stress conditions. ROS outbreaks biomolecules and interrupts the unvarying mechanism of the cell that ultimately prods to cell death. Microbes, the highest normal inhabitants of diverse environments, have advanced complex physiological and metabolic mechanisms to manage with possibly toxic oxygen species produced by ecological stresses. The intricate mechanisms are involved in the plant microbiome. Increasing environmental variations during the incessant stress, growing an essential mark, and revealing plant-microbe association concerning protection against environmental challenges.
\end{abstract}

Keywords: Abiotic stress; agricultural productivity; defense mechanism; Phytomicrobiome.

(C) 2020 by the authors. This article is an open-access article distributed under the terms and conditions of the Creative Commons Attribution (CC BY) license (https://creativecommons.org/licenses/by/4.0/).

\section{Introduction}

Various stress conditions affect plants, and the prime cause of limiting crop production worldwide is abiotic stress [1,2]. Quantity or intensity are the factors on which the abiotic factor of the plant depends. For optimal growth of plants, a certain amount of abiotic environmental factors is required. Any alteration, which lacks the biochemical or natural environment from optimal environmental conditions, is recognized as abiotic stress \& perilously affects plant growth, development, and productivity [1]. They are enduring characteristics of almost all the globe's climatic zones since many hazardous environmental hazards, and these threats are enlisted by global environmental change and community increase [3-10]. Anomaly environmental circumstances create abiotic stresses that are the chief prohibitive agents for restricting crop generation [11,12]. Abiotic stresses include cold, heat, alkaline conditions, drought, light intensity, waterlogging, salinity, and nutrient deficiency [2,13-17]. 64\% of the worldwide land area is affected by drought, salinity by $6 \%, 13 \%$ by anoxia, mineral deprivation $9 \%$, soil basicity $15 \%$, and cold $57 \%$ [18]. By the results of soil weathering, degeneration, and salt stress, the world's 3.6 billion ha is influenced out of a total of 5.2 billion ha of dryland agriculture [19]. Plants adapt to the speedy modification and disease of environmental situations due to their original metabolic mechanisms [20]. Plant metabolism could get out of 
homeostasis when deviations are occurred in the external environment conditions [21]. In such conditions, plants will need to acquire few genetic and metabolic mechanisms in the cell it $[22,23]$. Plants hold a diversity of protection mechanisms to combat abiotic stress conditions [24]. These mechanisms involve the metabolic reprogramming in cellular systems to initiate biochemical functions of the extrinsic conditions [25-29]. Several times, with the living microbiome's guidance, plants reduce the burden of abiotic stresses [30,31]. Microbes are a vital component of the environmental system and important for crop generation. One of the important seeds of seeds is microorganisms that proliferate as they sprouted to form shared connections at the exterior or endophytic associations inside the rootlets, pedice, or leaflets. Plant microbiome gives superior assistance to the plants in acquiring complements, opposing diseases, and enduring abiotic stresses [30]. Microbial integrated metabolic and hereditary capabilities make them flexible animals to survive with ecological difficulties $[32,33]$. Their interactions with the plants prompted a few basic responses that advanced the floras' metabolic processes for resistance against abiotic stress situations [34]. Numerous researches reported the domineering features of the bacterial intercommunications with vegetation that offer mechanisms based on plant-microorganism unions that strengthened the molecular, cellular, and biochemical processes of plant resistance against stresses [35-41]. Studies on plant microbiome at physiological, biochemical, and molecular levels noted that plant-microbes connections communicate plant responses facing stress conditions. Technological advancements also promoted RNAi-mediated gene silencing, knowing gene-editing systems, proteomic examination, mutant technology, and metabolite profiling to disclose abounding molecular knowledge that helped increase our knowledge of microbe-associations. In this work, we have reviewed the influence of climatic stresses on shoots and opposition rejoinders induced in plants [42].

\section{How plants are affected by environmental stress?}

\subsection{Diminishing of the physiological process of the plant.}

Plants required an abiotic ecosystem for their physical and growth mechanism. An unfavorable abiotic environment is an elaborate set of stress situations that restrict plant extension and progress. Plants can distinguish and react to stresses in multiple ways that promote their nourishment [43-45]. Plants recognize the preceding experience to stress and the procedures related in defense, and over when the similar stress exposes, they can adapt consequently [46]. The most evident effect of unfavorable conditions appears at the beginning; at the cellular level, after that, physiological symptoms are apparent. Water stress antagonistically influences the anatomical status of plants consisting of the photosystem [47]. Extend contact of water stress decreases root development, decays water probable and reduces leaf size, stomatal opening, seed size, viability, and number, delays flowering, and restrains plant growth and productivity [48,49]. Hence, plants have sagaciously developed distinctive mechanisms to limit the application of optimal water possessions and normalize their progress until they expose to harsh conditions [50]. Disclosure of antagonistic light concentrations decreases the physiological means and negatively influences plant extension. Excess light proposes photooxidation, heightening the manipulation of ROS or reactive oxygen species to regulate enzymes and another biomolecule [51-53]. 


\subsection{Biochemical changes during environmental stress.}

Plant development is affected by several abiotic factors that limit crop production; diverse stages of acid settings disapprovingly disturb soil minerals that cause a nutrient lack in herbal and interrupt the normal anatomical ability for plant growth and its development [5456] - prolonged salinity exposure stress primes to harmfulness within the cell along with disruption to osmotic balance. Osmotic stresses, along with ionic centrals to transformed plant development and evolution [57]. Forbearance to salinity stress is needed to control osmotic and ionic equilibrium in the cells. For opposition via saltiness, plants defend subtle plant skins from higher salty parts or originating ions from roots or staying ions away from the cytoplasm [58]. Throughout icing circumstances, some plants exhibited a process to manage with unfriendly temperatures by promoting their defense rejoinder by the process of cold acclimation [59]. Subsequent sensing the stress, plants reveal a fast and compelling response to instate involved stress-specific signaling by manufacturing plant hormone and collection of phenolic acids and flavonoids [60-66].

\subsection{Generation of ROS.}

Abiotic stresses are the primary cause of the production of ROS. The generation and eradication of Reactive Oxygen Species are at equilibrium under typical settings. Under ecological stress, it interrupts this stability by swelling the manufacture of ROS is very harmful to the organism as it adversely impacts the biomolecules' function and structure. The ROS is produced in plants in mitochondria, peroxisomes, and chloroplasts. Due to the reduction of the electron transport system, oxygen radicals and hydrogen peroxide is generated in mitochondria. The foremost source of $\mathrm{O}_{2}$ and $\mathrm{H}_{2} \mathrm{O}_{2}$ are chloroplasts [67] due to higher oxygen pressure plus reduced molecular oxygen than in different organs in the ETS or electron transport chain in PSI [68]. By the act of the enzyme SOD or superoxide dismutase, Those superoxides are transformed into hydrogen peroxide. Hydrogen peroxide is also accountable for the creation of radicals of hydroxyl. It has been registered that peroxisomes are a chief manufacturer of $\mathrm{H} 2 \mathrm{O} 2$ i.e., hydrogen peroxide and answerable for the making of superoxides $\left(\mathrm{O}_{2}-\right)$. In the peroxisomal matrix, in the occurrence of the enzyme xanthine oxidase produces $\mathrm{O}_{2}$ - radicals, the corrosion of xanthine and hypoxanthine to uric acid [69]. They destroy the biomolecules such as carbohydrates, lipids, proteins, and Deoxyribo Nucleic Acid, which primes to cell death [21].

\section{Molecular and physiological defense process of plants against conservational stress}

Plants cunningly sense and defense in opposition to the altering conservational situations. Their tactics and reactions to abiotic stresses involve bilateral metabolic crosstalk within various biosynthetic passages. Root construction is tactful in detecting abiotic stress signs and retorting consequently in the earth [70]. It is a complicated process that includes variations at the cellular, physiological, metabolic, and genetic levels [71]. The major influence of abiotic stresses is produced water-deficient situations within cells trailed by molecular, biochemical, and phenotypic action against stresses [47, 72]. Plants encountered multiple stresses in the background to the complexity of their replies to multiple stresses compared to individual stress. The problem occurs due to triggering distinct gene appearance and metabolic procedure in cells versus individual stresses encountered. Sufferance to stresses is a vital phenomenon, including different stages of plant development. Abiotic stress responses may 
lessen or increase plants' vulnerability to biotic stresses that began due to bugs or pathogens [73]. This becomes more important in crops because, in various farming schemes, maximum crops raise in uncomplimentary ecological circumstances controlled to the genetic probability of the plants for progress and maturation [1].

\subsection{Plant responses against drought stress.}

Floras are delicate to water stress. Through scarcity situations, peroxidation persuaded that primes to worrying antioxidant processes [74,75]. Rehydrating more condensed the peroxidation level and rejuvenated the growth and maturation of newly growing plant components and the opening of stomata. In roots, both drouth and waterlogging lead to greater accumulation of ROS [74]. Drouth responses vary from different flora species into account of SOD enzyme action that achieved a grave part in antioxidant uptake [75]. In bluegrass, SOD movement was not prejudiced by drought stress, and gene mien of FeSOD and $\mathrm{Cu} / \mathrm{ZnSOD}$ is unregulated. In Alfalfa, CU/ZnSOD and FeSOD are upregulated by drought stress, portentous that defense comebacks vary from species and tissues $[21,76]$. An improved salts level in the topsoil is harmful to the plant cells, and various cells in a tissue respond varyingly to the stresses produced due to salinity [77]. Stressed cells are harmful to their site, whether at the root exterior or inside tissues and transformed their gene expression during the stress condition [78]. The topsoil's osmotic potential declined because of the heightened level of salt, which mains to ion deadliness in the plants. This state can unfavorably affect the plants' composition by subduing seed germination and progress of the seedlings and early oldness of the plants and finally causing the end of it $[79,80]$. Salinity stress declines the levels of the amino acids, such as methionine, arginine, and cysteine. Proline combination in the cells is a protruding lessened method from salinity stress [81]. Similarly, nitric oxide production, initiation of antioxidant enzymes, regulation of hormones, and mixing of glycine betaine are some other variations within plants during brininess stress. This chiefly happens due to water insufficiency and degeneration in the nutrient approachability induced due to high salinity that disrupts plant tissues and skeptically influences crop productivity [82].

\subsection{Plant responses against heat stress.}

Heat stress is a critical agricultural problem. It unfavorably impacts practical, structural, biochemical, and genetic adjustments in plants that affect crop generation. Impeccable research on plant restrain processes against heat stress could assist in the advancement of better appearances for crop potency [83]. High temperature negatively reshapes plants during several growth stages. It diminishes seed sprouting, shakes photosynthetic activities, and deteriorates membrane permeability [75]. Plants answer against heat stress by moderating the level of metabolites, phytohormones, growing the declaration of heat shock and associated proteins, and accumulation of ROS [84]. Along with the maintenance of membrane stability and activation of mitogen-activated protein kinase and calcium-dependent protein kinase, scavenging of ROS, chaperone signaling, assembling of antioxidant metabolites, and transcriptional modulation is also included in the defense mechanism in plants against heat stress $[85,83]$. 


\subsection{Plant responses against multiple stress conditions.}

Plants are a more effective rejoinder in opposition to numerous stress circumstances rather than exact stress alone. Many stresses reduce the detrimental, damaging influence of each other afterward, increasing the possibility of plants' improved existence. It has been described that the combined result of ozone and drought in plants carried about better-quality lenience [86]. The cumulative effect was responsible for abridged stomatal conductance. Amplified the level of ascorbic acid and glutathione passably scavenges ROS. Besides, it is a worrying task for plants to contest to a particular stress, particularly when it is emergent in the field from numerous stresses. Multiple stresses arise at the same time in field conditions and thus occur concurrently in field situations and so mitigating plant procedures to battle with hurriedly changeable ecological settings [87].

\subsection{Role of plant hormones in responses to stress conditions.}

Plant hormones are vital for plant evolution and expansion and contain defense mechanisms against environmental stresses [88]. Plants address their physiological sources for arranging unfavorable environmental situations that make them abnormally susceptible to biotic stresses [89,90]. Abscisic acid-mediated abiotic stress rejoinder pathways are most valuable, shadowed by other phytohormone-dependent defense paths, namely, jasmonic acid, salicylic acid ethylene (ET) that aggravate plants for ecological stress reply. It has been inspected that jasmonic acid has effective defense responses against necrotrophs [91].

\section{Plant microbiome: role in stress and its mechanism}

The plant-microbial connections are authoritative for both the assistants' alteration and existence in any environmental circumstances. The purpose of microorganisms to surge abiotic stresses in plants has enticed investigators' attention in recent decades [92-94]. Microbes, with their possible intrinsic metabolic and genetic abilities, contribute to reducing abiotic stresses in the plants [95]. The function of several rhizomicrobes fits the genera of Azotobacter, Pseudomonas, Azospirillum, Rhizobium, Pantoea, Bradyrhizobium, Bacillus, Burkholderia, Enterobacter, Trichoderma, and Cyanobacteria in plant extension and fighting various environmental difficulties [96-102]. It has been published that Trichoderma harzianum responses in opposition to stress in rice by regulating the stress-related genes, namely, malondialdehyde, dehydrin, and aquaporin genes, counting physical limits. Numerous microorganisms persuade plant retorts, which changed the level of countless defense antioxidant enzymes, phytohormones, polysaccharides, and proteins, for example, Rhizobacteria-induced drought endurance and resilience [103]. These increasements make plants able to cope up with environmental stress conditions [104]. Improved oil content in Brassica juncea affected with $\mathrm{NaCl}$ was testified by the treatment of $T$. harzianum that enhanced the uptake of vital nutrients, improved aggregation of osmolytes, and antioxidants as well as reduced the uptake of $\mathrm{NaCl}$ [44]. Followed by such reports, Trichoderma synthesizes 1-aminocyclopropane-1-carboxylate (ACC) deaminase to amend salinity stress [105]. Similarly, Pseudomonas sp. and Acinetobacter sp. increase indole acidic acid (IAA) and ACC deaminase in oats and barley under salinity stress [106, 107]. It has been reported that the Streptomyces sp. strain PGPA39 alleviated salinity stress and promoted progress in tomato plants [108]. Burkholderia phytofirmans strain PsJN combat drouth stress in wheat, [109], maize, [110], and salinity stress in Arabidopsis thaliana [111]. 


\subsection{Physiological mechanism of phytomicrobiome against stress.}

Numerous researches have heightened our perception of physiological processes connected with roots, chemical molecules generated by roots, signaling within microbes and root, and potential defense mechanisms [112-116]. Academics have agreed on distinct care to microbes allied with root in the soil, amongst other symbiotic relations between many plants and microbes. Mycorrhiza is well-known for fungal settlement inside or outside the cell that assists in nutrient supposition [117]. Rhizobacteria from root buds of leguminous plants included fixing nitrogen and transport it to the plants. These associations have given data about the general association since plants have shaped constituent and diagnostic protection mechanism to keep away from catastrophic infrastructures [118].

\subsection{Cross talks between plants and microbes during stress conditions.}

There is frequent crosstalk between florae and bacteria throughout their intercommunication using different signaling particles. Several microorganisms are injurious to plants that bound growth and development. To recognize certain compounds released by microbes and enhance defense responses, plants have various mechanisms. The plant signaling hormones, namely, salicylic acid, jasmonic acid, and ET are used to activate defense mechanisms during the interaction between plants and microbes in response to stress conditions $[119,120]$. Plants recognize pathogens by identifying extracellular particles that are named pathogen-associated molecular patterns (PAMPs) or microbe-associated molecular patterns, namely, bacterial flagellin, Ef-TU proteins, peptidoglycans, and lipopolysaccharides [121], and/or intracellular effector tissue or proteins destruction utilizing pattern recognition receptor (PRR) proteins present on the cell exterior or within the cell [121-123]. The plant immune system constitutes of four-level. In level 1, PAMPs of microorganisms are identified. They bind to unique PRRs based on the cell exterior that initiates the plant resistant structure and outcomes to boosted immunity (PTI), which inhibits colonization and proliferation. In level 2, several pathogens predisposed effecters that improve virulency. The effectors delay with PTI and prime to effector-triggered susceptibility. In level 3, nucleotide-binding leucine-rich replicate receptor proteins identify the effector, which triggered effector-triggered immunity (ETI) that results in disease resistance. In level 4, natural selection has triggered pathogens to conquer ETI by emerging effectors, encouraging virulence until plants have evolved new receptors $[35,121,124,125]$.

\section{Impact of plant growth-promoting bacteria (PGPB) on plants}

PGPB is enhancing plant growth and sufferance against environmental stress. Plants are uncovered to diverse abiotic stress settings. Phytohormones show a vibrant part in representing salicylic acid, abscisic acid, jasmonic acid, and ET that react to stress, defending plants from different environmental challenges [126]. Studies reported that ACC deaminase activity of PGPB could regulate the stresses in plants [127-129]. The PGPB helps in combating abiotic stresses and enhances crop productivity, including maize, rice, soybean, and barley [130-133]. Enhanced root inhabiting capability of Pseudomonas sp. sideways with its ability to produce exo-polysaccharides stimulus upgraded resistance in retort to salinity in rice during germination [131]. Similarly, it has been exposed that immunizing of Bacillus pumilus improves rice progress in answer to heavy metal and salinity stresses [70]. 


\subsection{Phytohormones.}

Phytohormones play a pivotal role in plants' defense mechanisms. Plants respond and modify to abiotic stresses by adjusting the phytohormone levels. Some reports have exposed that PGPB fortifies plant development by indirect or direct systems. In the straight process, microbes accumulate phytohormones, for example, gibberellins, IAA, ET, and cytokinin that invigorate plant development and regulate the hormone level, that may furthermore oppose to phytopathogens [132-144]. In an indirect process, the bacteria activate plant battle by manufacturing compounds that can control hormone levels. PGPB can likewise animate plant development by communicating the compound ACC deaminase that severs ACC to alkali and $\alpha$-ketobutyrate, diminishing the plants' ET amount [145-148]. Usually, plants generate low ET that is appreciated for plant growth and upgrading. Further, among plants' stress reactions, the prolonged ET biogenesis is referred to as "stress ET" [146, 149]. That is a reaction to biotic and abiotic stress conditions [150,151].

\subsection{Root colonization.}

Rhizobacteria are inhabiting plant roots amongst numerous stages of plant ripening, and they can multiply on roots to accumulate a common association among microorganisms and plants, where these conversations give benefits to both the partners [152,153]. The bacterial cluster process to process and vie for carbon origin in the rhizosphere depends on the combination of plant root exudates [154]. Once the microscopic organisms settle the root, they can reside on the outside of the roots (epiphytic) or can penetrate the root and roll out into the insubstantial parts of the flora and vascular tissue cortex (endophytic) [155, 156]. Many scholars observed that Gram-positive and Gram-negative microbes intrude into the root through the horizontal roots, root hair, and primary root [157-169]. Moreover, it has been proclaimed that Curvularia protuberate microbes inhabit the root and defense Solanum lycopersicum and Dichanthelium lanuginosum plants from dehydration temperature stress conditions [92].

\subsection{Quorum sensing mechanism.}

Quorum detection is the procedure of the announcement between cells in microorganisms by tempting diverse substances. This inspires the bacterial collections to react quickly, hinder competing creatures, improve complement acceptance, and regulate to varying ecological situations. Likewise, it checks the bacterial size and populace status. 2 - heptyl -3hydroxy - 4 - quinoline, autoinducer - 2, and N-acyl-homoserine lactones (AHLs) are used as a part of the cell to cell intercommunication in the microbial group to occur a few actions and effect them to work more like a private part. These representing subdivisions are extraordinary among the bacteriological species. Cis-11-methyl-2-dodecanoic acid in Xanthomonas, AHLs in Proteobacteria, oligopeptides in Gram-positive microorganisms, and gammabutyrolactones in Streptomyces are acted as signaling molecules [160].

\section{Functions and ecology of the plant microbiome}

For the host, many purposes of the plant microbes are needed. Numerous floras cannot initiate their lifespan deprived of microorganisms' support, for example, mosses [161] and orchids, which needs the aid of specific fungi, commonly Rhizoctonia, to sprout [162]. The 
germination-advancing fungus Rhizoctonia consists of convenient organisms and, additionally, pathogens. To stay far from any pathogenic collaboration after emerging, the host plant processes their assisting fungus. In these propagation bolster processes, microorganisms are fundamental, and this may be one aim that these foundations microorganisms are perpendicularly carried as looked for Sphagnum [163]. An emphatic impact on production was moreover created for plant-associated microbes such as Stenotrophomonas [164]. Generation of phytohormones, fixation of nitrogen, and the moving of phosphorus and minerals are a few of the processes by which these microbes promote floral germination [165].

\subsection{Promote stress resistance.}

The plant microbiome, unusually the root microbiome, is involved in the stability in opposition to biotic stress, by profitable about as a protective guard against soil-borne pathogens [166]. The elements include different direct interactions with plant pathogens and indirect connections throughout the plant by the stimulus of the immune system of plants [167]. In recent research, it has explained that the microbe is not only tangled in altering with biotic stress; it is also necessitated in protection against abiotic stress [168]. For example, the plant microbe has been risen to be connected with resistance versus drought and great salinities stresses. Researchers summarized that this plant microbiome is linked with cold adaptation, an indispensable factor forcing the evolution and production of harvests $[169,170]$.

\subsection{Plant development and growth.}

The plant microbiome also changes the subsequent plant metabolites that result in the addition of several metabolisms in plants. It has been considered for the flavor of berries and the construction of bioactive composites in therapeutic plants [171,172]. In an examination of A. thaliana, the rhizosphere microbes are involved in insect-eating features, which was most probably a repercussion of microbe-driven modifications in the metabolites of the leaf [173]. It has been analyzed that the removal of the floret microbe of Sambucus nigra results to a lowered terpene emanation in flower, which is pivotally included in propagation and in seed and fruit generation [174].

\subsection{Plant phenology.}

Studies on plant microbiome revealed the critical influence of the root microbe on plant phenology. It has been proclaimed that soil microbes influence the flowering time of a Boechera stricta [175]. The fruitful relocation of rhizosphere microbiomes from A. thaliana to Brassica rapa affected their blossoming times, bringing around comparable moves in flowering phenology [176,177]. Coadvancement of plants and associated microbial groups has been evaluated in the well-lit of culture-subordinate consequences got for the rhizosphere of wheat producers [178], sugar beet, lettuce, and maize, by the application of subterranean sequencing techniques $[179,180]$.

\section{Conclusions}

The antagonistic environmental situation over plant systems improves ROS production, directing to toxicity and producing oxidative damage at the cellular stage. Plants react to various abiotic stresses by complicated mechanisms requiring changes at cellular, physiological, genetic, and metabolic levels. The plant microbiome contributes primary 
assistance to the plants in receiving nutrients, combating opposition to contagions, and lasting abiotic stresses. The microbiome on plants is correlated with each other via multiple metabolic crosstalks and form stress resisting tactics. Microbes produce different metabolites that act as flags during stress conditions. Plants can identify specific composites produced by microbes and begin defense mechanisms in response to stressful circumstances. Plant-associated microorganisms are not only involved in stress toleration; however, they additionally regulate plant germination and progress. The morphology and metabolism of floras and their microbiomes are correlated. Both control the functioning of several crops to enhance crop productions below different environmental circumstances.

\section{Funding}

This review received no external funding.

\section{Acknowledgments}

This review has no acknowledgment.

\section{Conflicts of Interest}

The author declares no conflict of interest.

\section{References}

1. Bray, E.A. Response to abiotic stress. Biochemistry and molecular biology of plants 2000, 1158-1203.

2. Wang, W.; Vinocur, B.; Altman, A. Plant responses to drought, salinity and extreme temperatures: towards genetic engineering for stress tolerance. Planta 2003, 218, 1-14, https://doi.org/10.1007/s00425-003-11055.

3. Gleick, P.H. Water, War \& Peace in the Middle East. Environment: Science and Policy for Sustainable Development 1994, 36, 6-42, https://doi.org/10.1080/00139157.1994.9929154.

4. Gleick, P.H. Water in crisis: paths to sustainable water use. Ecological applications 1998, 8, 571-579, https://doi.org/10.1890/1051-0761(1998)008[0571:WICPTS]2.0.CO;2.

5. Gleick, P. H. The World's Water 200-2001: The Biennial Report on Freshwater Resources. Pacific Institute for Studies in Development, Environment, and Security, Oakland, California. Island Press, Washington, DC. Volume 1, 2000.

6. Bhatt, P.; Verma, A.; Verma, S.; Anwar, S.; Parteek.; Mudila H.Chen, S. Understanding Phytomicrobiome: A Potential Reservoir for Better Crop Management. Sustainability 2020, 12, 5446; doi:10.3390/su12135446.

7. Ab Rahman, S. F. S.; Singh, E.; Pieterse, C. M.; Schenk, P. M. J. Emerging microbial biocontrol strategies for plant pathogens. Plant Sci. 2018, 267, 102-111. doi: 10.1016/j.plantsci.2017.11.012.

8. Behm, J. E.; Geurts, R.; Kiers, E. T. Parasponia: a novel system for studying mutualism stability. Trends Plant Sci. 2020, 19, 757-763. doi: 10.1016/j.tplants.2014.08.007.

9. Liu, H.; Brettell, L. E. Plant defense by VOC-induced microbial priming. Trends Plant Sci. 2019, 24, 187189. doi: 10.1016/j.tplants.2019.01.008

10. Cordovez, V.; Dini-Andreote, F.; Carrión, V. J.; Raaijmakers, J. M. Ecology and evolution of plant microbiomes. Annu. Rev. Microbiol. 2019, 73, 69-88. doi: https://doi.org/10.1146/annurev-micro-090817062524.

11. Padgham, J. Agricultural development under a changing climate: opportunities and challenges for adaptation. World Bank. 2009, https://doi.org/10.1596/28125.

12. Grayson, M. Agriculture and drought. Nature 2013, 501, S1-S1, https://doi.org/10.1038/501S1a.

13. Chaves, M.M.; Oliveira, M.M. Mechanisms underlying plant resilience to water deficits: prospects for watersaving agriculture. Journal of Experimental Botany 2004, 55, 2365-2384, https://doi.org/10.1093/jxb/erh269.

14. Agarwal, S.; Grover, A. Molecular biology, biotechnology and genomics of flooding-associated low $\mathrm{O} 2$ stress response in plants. Critical Reviews in Plant Sciences 2006, 25, 1-21, https://doi.org/10.1080/07352680500365232.

15. Nakashima, K.; Yamaguchi-Shinozaki, K. Regulons involved in osmotic stress-responsive and cold stressresponsive gene expression in plants. Physiologia Plantarum 2006, 126, 62-71, https://doi.org/10.1111/j.1399-3054.2005.00592.x. 
16. Hirel, B.; Le Gouis, J.; Ney, B.; Gallais, A. The challenge of improving nitrogen use efficiency in crop plants: towards a more central role for genetic variability and quantitative genetics within integrated approaches. Journal of Experimental Botany 2007, 58, 2369-2387, https://doi.org/10.1093/jxb/erm097.

17. Bailey-Serres, J.; Voesenek, L.A.C.J. Flooding Stress: Acclimations and Genetic Diversity. Annual Review of Plant Biology 2008, 59, 313-339, https://doi.org/10.1146/annurev.arplant.59.032607.092752.

18. Mittler, R. Abiotic stress, the field environment and stress combination. Trends in Plant Science 2006, 11, 15-19, https://doi.org/10.1016/j.tplants.2005.11.002.

19. Riadh, K.; Wided, M.; Hans-Werner, K.; Chedly, A. Responses of halophytes to environmental stresses with special emphasis to salinity. Advances in Botanical Research 2010, 53, 117-145, https://doi.org/10.1016/S0065-2296(10)53004-0.

20. Simontacchi, M.; Galatro, A.; Ramos-Artuso, F.; Santa-María, G.E. Plant survival in a changing environment: the role of nitric oxide in plant responses to abiotic stress. Frontiers in plant science 2015, 6 , 977, https://doi.org/10.3389/fpls.2015.00977.

21. Foyer, C.H.; Noctor, G. Oxidant and antioxidant signalling in plants: a re-evaluation of the concept of oxidative stress in a physiological context. Plant, Cell \& Environment 2005, 28, 1056-1071, https://doi.org/10.1111/j.1365-3040.2005.01327.x.

22. Apel, K.; Hirt, H. REACTIVE OXYGEN SPECIES: Metabolism, Oxidative Stress, and Signal Transduction. $\begin{array}{llllll}\text { Annual Review } & \text { B } & \text { Blology } & \text { 2004, } & \text { 35, }\end{array}$ https://doi.org/10.1146/annurev.arplant.55.031903.141701.

23. Gill, S.S.; Tuteja, N. Reactive oxygen species and antioxidant machinery in abiotic stress tolerance in crop plants. Plant Physiology and Biochemistry 2010, 48, 909-930, https://doi.org/10.1016/j.plaphy.20https://doi.org/10.08.016.

24. Yolcu, S.; Ozdemir, F.; Güler, A.; Bor, M. Histone acetylation influences the transcriptional activation of POX in Beta vulgaris L. and Beta maritima L. under salt stress. Plant Physiology and Biochemistry 2016, 100, 37-46, https://doi.org/10.1016/j.plaphy.2015.12.019.

25. Heil, M.; Bostock, R.M. Induced Systemic Resistance (ISR) Against Pathogens in the Context of Induced Plant Defences. Annals of Botany 2002, 89, 503-512, https://doi.org/10.1093/aob/mcf076.

26. Swarbrick, P.J.; Schulze-Lefert, P.; Scholes, J.D. Metabolic consequences of susceptibility and resistance (race-specific and broad-spectrum) in barley leaves challenged with powdery mildew. Plant, Cell \& Environment 2006, 29, 1061-1076, https://doi.org/10.1111/j.1365-3040.2005.01472.x.

27. Shao, H.-B.; Chu, L.-Y.; Jaleel, C.A.; Zhao, C.-X. Water-deficit stress-induced anatomical changes in higher plants. Comptes Rendus Biologies 2008, 331, 215-225, https://doi.org/10.1016/j.crvi.2008.01.002.

28. Bolton, M.D. Primary Metabolism and Plant Defense-Fuel for the Fire. Molecular Plant-Microbe Interactions 2009, 22, 487-497, https://doi.org/10.1094/MPMI-22-5-0487.

29. Massad, T.J.; Dyer, L.A.; Vega C, G. Costs of Defense and a Test of the Carbon-Nutrient Balance and Growth-Differentiation Balance Hypotheses for Two Co-Occurring Classes of Plant Defense. PLOS ONE 2012, 7, https://doi.org/10.1371/journal.pone.0047554.

30. Mickelbart, M.V.; Hasegawa, P.M.; Bailey-Serres, J. Genetic mechanisms of abiotic stress tolerance that translate to crop yield stability. Nature Reviews Genetics 2015, 16, 237-251, https://doi.org/10.1038/nrg3901.

31. Turner, T.R.; James, E.K.; Poole, P.S. The plant microbiome. Genome Biology 2013, 14, https://doi.org/10.1186/gb-2013-14-6-209.

32. Ngumbi, E.; Kloepper, J. Bacterial-mediated drought tolerance: current and future prospects. Applied Soil Ecology 2016, 105, 109-125, https://doi.org/10.1016/j.apsoil.2016.04.009.

33. Sessitsch, A.; Hardoim, P.; Döring, J.; Weilharter, A.; Krause, A.; Woyke, T.; Mitter, B.; Hauberg-Lotte, L.; Friedrich, F.; Rahalkar, M.; Hurek, T.; Sarkar, A.; Bodrossy, L.; van Overbeek, L.; Brar, D.; van Elsas, J.D.; Reinhold-Hurek, B. Functional Characteristics of an Endophyte Community Colonizing Rice Roots as Revealed by Metagenomic Analysis. Molecular Plant-Microbe Interactions 2011, 25, 28-36, https://doi.org/10.1094/MPMI-08-11-0204.

34. Singh, R. Microorganism as a tool of bioremediation technology for cleaning environment: a review. Proceedings of the International Academy of Ecology and Environmental Sciences 2014, 4.

35. Nguyen, D.; Rieu, I.; Mariani, C.; van Dam, N.M. How plants handle multiple stresses: hormonal interactions underlying responses to abiotic stress and insect herbivory. Plant Molecular Biology 2016, 91, 727-740, https://doi.org/10.1007/s11103-016-0481-8.

36. Bakker, M.G.; Manter, D.K.; Sheflin, A.M.; Weir, T.L.; Vivanco, J.M. Harnessing the rhizosphere microbiome through plant breeding and agricultural management. Plant and Soil 2012, 360, 1-13, https://doi.org/10.1007/s11104-012-1361-x.

37. Ortiz-Castro, R.; López-Bucio, J. Phytostimulation and root architectural responses to quorum-sensing signals and related molecules from rhizobacteria. Plant Sci. 2019, 284, 135-142. doi: 10.1016/j.plantsci.2019.04.010

38. Ricci, E.; Schwinghamer, T.; Fan, D.; Smith, D. L.; Gravel, V. Growth promotion of greenhouse tomatoes with Pseudomonas sp. and Bacillus sp. biofilms and planktonic cells. Appl. Soil Ecol. 2019, 138, 61-68. doi: https://doi.org/10.1016/j.apsoil.2019.02.009

https://biointerfaceresearch.com/ 
39. Sessitsch, A.; Pfaffenbichler, N.; Mitter, B. Microbiome applications from Lab to Field: Facing complexity. Trends Plant Sci. 2019, 24, 194-198. doi: 10.1016/j.tplants.2018.12.004. doi: https://doi.org/10.1016/j.tplants.2018.12.004

40. Yoneyama, K.; Xie, X.; Yoneyama, K.; Nomura, T.; Takahashi, I.; Asami, T. Regulation of biosynthesis, perception, and functions of strigolactones for promoting arbuscular mycorrhizal symbiosis and managing root parasitic weeds. Pest Manag. Sci. 2019, 75, 2353-2359. doi: 10.1002/ps.5401

41. Zhang, Z.; Xu, Y.; Song, G.; Gao, X.; Zhao, Y.; Jia, M. Phytophthora sojae zoospores differ in chemotaxis to the root and root exudates of host soybean and nonhost common bean. J. Gen. Plant Pathol.2019, 85, 201210. doi: https://doi.org/10.1007/s10327-019-00839-9

42. Onaga, G.; Wydra, K. Advances in plant tolerance to abiotic stresses. Plant Genomics 2016, 229-272, https://doi.org/10.5772/64350.

43. Farrar, K.; Bryant, D.; Cope-Selby, N. Understanding and engineering beneficial plant-microbe interactions: plant growth promotion in energy crops. Plant Biotechnology Journal 2014, 12, 1193-1206, https://doi.org/10.1111/pbi.12279.

44. Crane, T.A.; Roncoli, C.; Hoogenboom, G. Adaptation to climate change and climate variability: The importance of understanding agriculture as performance. NJAS-Wageningen Journal of Life Sciences 2011, 57, 179-185, https://doi.org/10.1016/j.njas.2010.11.002.

45. Ahmad, P.; Hashem, A.; Abd-Allah, E.F.; Alqarawi, A.A.; John, R.; Egamberdieva, D.; Gucel, S. Role of Trichoderma harzianum in mitigating $\mathrm{NaCl}$ stress in Indian mustard (Brassica juncea L) through antioxidative defense system. 2015, 6, https://doi.org/10.3389/fpls.2015.00868.

46. Jiang, Q.-Y.; Zhuo, F.; Long, S.-H.; Zhao, H.-D.; Yang, D.-J.; Ye, Z.-H.; Li, S.-S.; Jing, Y.-X. Can arbuscular mycorrhizal fungi reduce Cd uptake and alleviate Cd toxicity of Lonicera japonica grown in Cd-added soils? Scientific Reports 2016, 6, 1-9, https://doi.org/10.1038/srep21805.

47. Hilker, M.; Schwachtje, J.; Baier, M.; Balazadeh, S.; Bäurle, I.; Geiselhardt, S.; Hincha, D.K.; Kunze, R.; Mueller-Roeber, B.; Rillig, M.C.; Rolff, J.; Romeis, T.; Schmülling, T.; Steppuhn, A.; van Dongen, J.; Whitcomb, S.J.; Wurst, S.; Zuther, E.; Kopka, J. Priming and memory of stress responses in organisms lacking a nervous system. Biological Reviews 2016, 91, 1118-1133, https://doi.org/10.1111/brv.12215.

48. Xu, Z.Z.; Zhou, G.S. Combined effects of water stress and high temperature on photosynthesis, nitrogen metabolism and lipid peroxidation of a perennial grass Leymus chinensis. Planta 2006, 224, 1080-1090, https://doi.org/10.1007/s00425-006-0281-5.

49. Osakabe, Y.; Osakabe, K.; Shinozaki, K.; Tran, L.S.P. Response of plants to water stress. Frontiers in plant science 2014, 5, https://doi.org/10.3389/fpls.2014.00086.

50. Xu, Z.; Jiang, Y.; Jia, B.; Zhou, G. Elevated-CO2 Response of Stomata and Its Dependence on Environmental Factors. 2016, 7, https://doi.org/10.3389/fpls.2016.00657.

51. Osakabe, Y.; Arinaga, N.; Umezawa, T.; Katsura, S.; Nagamachi, K.; Tanaka, H.; Ohiraki, H.; Yamada, K.; Seo, S.U.; Abo, M.; Yoshimura, E.; Shinozaki, K.; Yamaguchi-Shinozaki, K. Osmotic stress responses and plant growth controlled by potassium transporters in Arabidopsis. Plant Cell 2013, 25, 609-624.

52. Li, Z.; Wakao, S.; Fischer, B.B.; Niyogi, K.K. Sensing and responding to excess light. Annual review of plant biology 2009, 60, 239-260, https://doi.org/10.1146/annurev.arplant.58.032806.103844.

53. Koini, M.A.; Alvey, L.; Allen, T.; Tilley, C.A.; Harberd, N.P.; Whitelam, G.C.; Franklin, K.A. High Temperature-Mediated Adaptations in Plant Architecture Require the bHLH Transcription Factor PIF4. Current Biology 2009, 19, 408-413, https://doi.org/10.1016/j.cub.2009.01.046.

54. Thomson, M.J.; Ismail, A.M.; McCouch, S.R.; Mackill, M.J.; Pareek, A.; Sopory, S.K.; Bohnert, H.J. Govindjee. Abiotic Stress Adaptation in Plants: Physiological, molecular and genomic foundation. 2010.

55. Bromham, L.; Saslis-Lagoudakis, C.H.; Bennett, T.H.; Flowers, T.J. Soil alkalinity and salt tolerance: adapting to multiple stresses. Biology Letters 2013, 9, https://doi.org/10.1098/rsbl.2013.0642.

56. Emamverdian, A.; Ding, Y.; Mokhberdoran, F.; Xie, Y. Heavy Metal Stress and Some Mechanisms of Plant Defense Response. The Scientific World Journal 2015, 2015, https://doi.org/10.1155/2015/756120.

57. Rorison, I.H. The response of plants to acid soils. Experientia 1986, 42, 357-362, https://doi.org/10.1007/BF02118616.

58. Munns, R.; Tester, M. Mechanisms of salinity tolerance. Annu. Rev. Plant Biol. 2008, 59, 651-681, https://doi.org/10.1146/annurev.arplant.59.032607.092911.

59. Silva, E.N.; Ribeiro, R.V.; Ferreira-Silva, S.L.; Viégas, R.A.; Silveira, J.A.G. Comparative effects of salinity and water stress on photosynthesis, water relations and growth of Jatropha curcas plants. Journal of Arid Environments 2010, 74, 1130-1137, https://doi.org/10.1016/j.jaridenv.2010.05.036.

60. Thomashow, M.F. Molecular basis of plant cold acclimation: insights gained from studying the CBF cold response pathway. Plant Physiol 2010, 154, 571-577, https://doi.org/10.1104/pp.110.161794.

61. Chinnusamy, V.; Schumaker, K.; Zhu, J.K. Molecular genetic perspectives on crosstalk and specificity in abiotic stress signalling in plants. Journal of Experimental Botany 2004, 55, 225-236, https://doi.org/10.1093/jxb/erh005.

62. Andreasson, E.; Ellis, B. Convergence and specificity in the Arabidopsis MAPK nexus. Trends in Plant Science 2010, 15, 106-113, https://doi.org/10.1016/j.tplants.2009.12.001. 
63. Spoel, S.H.; Dong, X. Making sense of hormone crosstalk during plant immune responses. Cell host \& microbe 2008, 3, 348-351, https://doi.org/10.1016/j.chom.2008.05.009.

64. Qin, F.; Shinozaki, K.; Yamaguchi-Shinozaki, K. Achievements and challenges in understanding plant abiotic stress responses and tolerance. Plant and Cell Physiology 2011, 52, 1569-1582, https://doi.org/10.1093/pcp/pcr106.

65. Todaka, D.; Nakashima, K.; Shinozaki, K.; Yamaguchi-Shinozaki, K. Toward understanding transcriptional regulatory networks in abiotic stress responses and tolerance in rice. Rice 2012, 5, https://doi.org/10.1186/1939-8433-5-6.

66. Singh, D.P.; Prabha, R.; Yandigeri, M.S.; Arora, D.K. Cyanobacteria-mediated phenylpropanoids and phytohormones in rice (Oryza sativa) enhance plant growth and stress tolerance. Antonie Van Leeuwenhoek 2011, 100, 557-568, https://doi.org/10.1007/s10482-011-9611-0.

67. Tiwari, S.; Singh, P.; Tiwari, R.; Meena, K.K.; Yandigeri, M.; Singh, D.P.; Arora, D.K. Salt-tolerant rhizobacteria-mediated induced tolerance in wheat (Triticum aestivum) and chemical diversity in rhizosphere enhance plant growth. Biology and Fertility of soils 2011, 47, https://doi.org/10.1007/s00374011-0598-5.

68. Davletova, S.; Rizhsky, L.; Liang, H.; Shengqiang, Z.; Oliver, D.J.; Coutu, J.; Shulaev, V.; Schlauch, K.; Mittler, R. Cytosolic ascorbate peroxidase 1 is a central component of the reactive oxygen gene network of Arabidopsis. The Plant cell 2005, 17, 268-281, https://doi.org/10.1105/tpc.104.026971.

69. Dat, J.; Vandenabeele, S.; Vranová, E.; Van Montagu, M.; Inzé*, D.; Van Breusegem, F. Dual action of the active oxygen species during plant stress responses. Cellular and Molecular Life Sciences CMLS 2000, 57, 779-795, https://doi.org/10.1007/s000180050041.

70. Halliwell, B.; Gutteridge, J.M. Free radicals in biology and medicine. Oxford University Press, USA. 2015.

71. Khan, M.A.; Gemenet, D.C.; Villordon, A. Root System Architecture and Abiotic Stress Tolerance: Current Knowledge in Root and Tuber Crops. 2016, 7, https://doi.org/10.3389/fpls.2016.01584.

72. Atkinson, N.J.; Urwin, P.E. The interaction of plant biotic and abiotic stresses: from genes to the field. Journal of Experimental Botany 2012, 63, 3523-3543, https://doi.org/10.1093/jxb/ers100.

73. Almoguera, C.; Coca, M.A.; Jordano, J. Differential Accumulation of Sunflower Tetraubiquitin mRNAs during Zygotic Embryogenesis and Developmental Regulation of Their Heat-Shock Response. Plant Physiology 1995, 107, 765-773, https://doi.org/10.1104/pp.107.3.765.

74. Rizhsky, L.; Liang, H.; Shuman, J.; Shulaev, V.; Davletova, S.; Mittler, R. When Defense Pathways Collide. The Response of Arabidopsis to a Combination of Drought and Heat Stress. Plant Physiology 2004, 134, 1683-1696. https://doi.org/10.1104/pp.103.033431.

75. Bian, S.; Jiang, Y. Reactive oxygen species, antioxidant enzyme activities and gene expression patterns in leaves and roots of Kentucky bluegrass in response to drought stress and recovery. Scientia Horticulturae 2009, 120, 264-270, https://doi.org/10.1016/j.scienta.2008.10.014.

76. Xu, Z.; Shimizu, H.; Ito, S.; Yagasaki, Y.; Zou, C.; Zhou, G.; Zheng, Y. Effects of elevated CO2, warming and precipitation change on plant growth, photosynthesis and peroxidation in dominant species from North China grassland. Planta 2014, 239, 421-435, https://doi.org/10.1007/s00425-013-1987-9.

77. Naya, L.; Ladrera, R.; Ramos, J.; González, E.M.; Arrese-Igor, C.; Minchin, F.R.; Becana, M. The Response of Carbon Metabolism and Antioxidant Defenses of Alfalfa Nodules to Drought Stress and to the Subsequent Recovery of Plants. Plant Physiology 2007, 144, 1104-1114, https://doi.org/10.1104/pp.107.099648.

78. Voesenek, L.A.C.J.; Pierik, R. Plant Stress Profiles. 2008, 320, 880-881, https://doi.org/10.1126/science.1158720.

79. Dinneny, J.R.; Long, T.A.; Wang, J.Y.; Jung, J.W.; Mace, D.; Pointer, S.; Barron, C.; Brady, S.M.; Schiefelbein, J.; Benfey, P.N. Cell Identity Mediates the Response of Arabidopsis Roots to Abiotic Stress. 2008, 320, 942-945, https://doi.org/10.1126/science.1153795.

80. McCue, K.F.; Hanson, A.D. Salt-inducible betaine aldehyde dehydrogenase from sugar beet: cDNA cloning and expression. Plant Molecular Biology 1992, 18, 1-11, https://doi.org/10.1007/BF00018451.

81. Hasegawa, P.M.; Bressan, R.A.; Zhu, J.-K.; Bohnert, H.J. Plant cellular and molecular responses to high salinity. Annual Review of Plant Physiology and Plant Molecular Biology 2000, 51, 463-499, https://doi.org/10.1146/annurev.arplant.51.1.463.

82. Matysik, J.; Alia, A.; Bhalu, B.; Mohanty, P. Molecular mechanism of quenching of reactive oxygen species by proline under stress in plants. Current Science 2002, 82, 525-32, https://doi.org/10.2307/24105959.

83. Gupta B.; Huang B. Mechanism of salinity tolerance in plants: Physiological, biochemical, and molecular characterization. Int J Genomics 2014, 7.

84. Wahid, A.; Gelani, S.; Ashraf, M.; Foolad, M.R. Heat tolerance in plants: An overview. Environmental and Experimental Botany 2007, 61, 199-223, https://doi.org/10.1016/j.envexpbot.2007.05.011.

85. Iba, K. Acclimative response to temperature stress in higher plants: Approaches of gene engineering for temperature tolerance. Annu Rev Plant Biol 2002, 53, 225-45, https://doi.org/10.1146/annurev.arplant.53.100201.160729.

86. Wang, L.J.; Li, S.L. Salicylic acid-induced heat or cold tolerance in relation to Ca2C homeostasis and antioxidant systems in young grape plants. Plant Sci, 2006, 170, 685-94, https://doi.org/10.1016/j.plantsci.2005.09.005. 
87. Iyer, N.J.; Tang, Y.; Mahalingam, R. Physiological, biochemical and molecular responses to a combination of drought and ozone in Medicago truncatula. Plant, Cell \& Environment 2013, 36, 706-720, https://doi.org/10.1111/pce.12008.

88. Rivero, R.M.; Mestre, T.C.; Mittler, R.O.N.; Rubio, F.; Garcia-Sanchez, F.; Martinez, V. The combined effect of salinity and heat reveals a specific physiological, biochemical and molecular response in tomato plants. Plant, Cell \& Environment 2014, 37, 1059-1073, https://doi.org/10.1111/pce.12199.

89. Wani, S.H.; Kumar, V.; Shriram, V.; Sah, S.K. Phytohormones and their metabolic engineering for abiotic stress tolerance in crop plants. The Crop Journal 2016, 4, 162-176, https://doi.org/10.1016/j.cj.2016.01.010.

90. De Torres Zabala, M.; Bennett, M.H.; Truman, W.H.; Grant, M.R. Antagonism between salicylic and abscisic acid reflects early host-pathogen conflict and moulds plant defence responses. The Plant Journal 2009, 59, 375-386, https://doi.org/10.1111/j.1365-313X.2009.03875.x.

91. Hey, S.J.; Byrne, E.; Halford, N.G. The interface between metabolic and stress signalling. Annals of Botany 2010, 105, 197-203, https://doi.org/10.1093/aob/mcp285.

92. Matilla, M.A.; Ramos, J.L.; Bakker, P.A.H.M.; Doornbos, R.; Badri, D.V.; Vivanco, J.M.; Ramos-González, M.I. Pseudomonas putida KT2440 causes induced systemic resistance and changes in Arabidopsis root exudation. Environmental Microbiology Reports 2010, 2, 381-388, https://doi.org/10.1111/j.17582229.2009.00091.x.

93. de Zelicourt, A.; Al-Yousif, M.; Hirt, H. Rhizosphere Microbes as Essential Partners for Plant Stress Tolerance. Molecular Plant 2013, 6, 242-245, https://doi.org/10.1093/mp/sst028.

94. Nadeem, S.M.; Ahmad, M.; Zahir, Z.A.; Javaid, A.; Ashraf, M. The role of mycorrhizae and plant growth promoting rhizobacteria (PGPR) in improving crop productivity under stressful environments. Biotechnology Advances 2014, 32, 429-448, https://doi.org/10.1016/j.biotechadv.2013.12.005.

95. Souza, R.D.; Ambrosini, A.; Passaglia, L.M. Plant growth-promoting bacteria as inoculants in agricultural soils. Genet Mol Biol, 2015, 38, 401-19, https://doi.org/10.1590/S1415-475738420150053.

96. Gopalakrishnan, S.; Sathya, A.; Vijayabharathi, R.; Varshney, R.K.; Gowda, C.L.L.; Krishnamurthy, L. Plant growth promoting rhizobia: challenges and opportunities. 3 Biotech 2015, 5, 355-377, https://doi.org/10.1007/s13205-014-0241-x.

97. Sahoo, R.K.; Ansari, M.W.; Pradhan, M.; Dangar, T.K.; Mohanty, S.; Tuteja, N. A novel Azotobacter vinellandii (SRIAz3) functions in salinity stress tolerance in rice. Plant Signaling \& Behavior 2014, 9, https://doi.org/10.4161/psb.29377.

98. Omar, M.N.; Osman, M.E.; Kasim, W.A.; Abd El-Daim, I.A. Improvement of salt tolerance mechanisms of barley cultivated under salt stress using Azospirillum brasiliense. Tasks Veg Sci 2009, 44, 133-47, https://doi.org/10.1007/978-1-4020-9065-3_15.

99. Tittabutr, P.; Piromyou, P.; Longtonglang, A.; Noisa-Ngiam, R.; Boonkerd, N.; Teaumroong, N. Alleviation of the effect of environmental stresses using co-inoculation of mungbean by Bradyrhizobium and rhizobacteria containing stress-induced ACC deaminase enzyme. Soil Science and Plant Nutrition 2013, 59, 559-571, https://doi.org/10.1080/00380768.2013.804391.

100. Meena, K.K.; Kumar, M.; Kalyuzhnaya, M.G.; Yandigeri, M.S.; Singh, D.P.; Saxena, A.K.; Arora, D.K. Epiphytic pink-pigmented methylotrophic bacteria enhance germination and seedling growth of wheat (Triticum aestivum) by producing phytohormone. Antonie van Leeuwenhoek 2012, 101, 777-786, https://doi.org/10.1007/s10482-011-9692-9.

101. Oliveira, C.A.; Alves, V.M.C.; Marriel, I.E.; Gomes, E.A.; Scotti, M.R.; Carneiro, N.P.; Guimarães, C.T.; Schaffert, R.E.; Sá, N.M.H. Phosphate solubilizing microorganisms isolated from rhizosphere of maize cultivated in an oxisol of the Brazilian Cerrado Biome. Soil Biology and Biochemistry 2009, 41, 1782-1787, https://doi.org/10.1016/j.soilbio.2008.01.012.

102. Sorty, A.M.; Meena, K.K.; Choudhary, K.; Bitla, U.M.; Minhas, P.S.; Krishnani, K.K. Effect of Plant Growth Promoting Bacteria Associated with Halophytic Weed (Psoralea corylifolia L) on Germination and Seedling Growth of Wheat Under Saline Conditions. Applied Biochemistry and Biotechnology 2016, 180, 872-882, https://doi.org/10.1007/s12010-016-2139-z.

103. Pandey, V.; Ansari, M.W.; Tula, S.; Yadav, S.; Sahoo, R.K.; Shukla, N.; Bains, G.; Badal, S.; Chandra, S.; Gaur, A.K.; Kumar, A.; Shukla, A.; Kumar, J.; Tuteja, N. Dose-dependent response of Trichoderma harzianum in improving drought tolerance in rice genotypes. Planta 2016, 243, 1251-1264, https://doi.org/10.1007/s00425-016-2482-x.

104. Kaushal, M.; Wani, S.P. Plant-growth-promoting rhizobacteria: drought stress alleviators to ameliorate crop production in drylands. Annals of Microbiology 2016, 66, 35-42, https://doi.org/10.1007/s13213-015-11123.

105. Brotman, Y.; Landau, U.; Cuadros-Inostroza, Á.; Takayuki, T.; Fernie, A.R.; Chet, I.; Viterbo, A.; Willmitzer, L. Trichoderma-Plant Root Colonization: Escaping Early Plant Defense Responses and Activation of the Antioxidant Machinery for Saline Stress Tolerance. PLoS Pathog 2013, 9, https://doi.org/10.1371/journal.ppat.1003221.

106. Chang, P.; Gerhardt, K.E.; Huang, X.-D.; Yu, X.-M.; Glick, B.R.; Gerwing, P.D.; Greenberg, B.M. Plant Growth-Promoting Bacteria Facilitate the Growth of Barley and Oats in Salt-Impacted Soil: Implications for 
Phytoremediation of Saline Soils. International Journal of Phytoremediation 2014, 16, 1133-1147, https://doi.org/10.1080/15226514.2013.821447.

107. Palaniyandi, S.A.; Damodharan, K.; Yang, S.H.; Suh, J.W. Streptomyces sp. strain PGPA39 alleviates salt stress and promotes growth of 'Micro Tom' tomato plants. Journal of Applied Microbiology 2014, 117, 766773, https://doi.org/10.1111/jam.12563.

108. Naveed, M.; Hussain, M.B.; Zahir, Z.A.; Mitter, B.; Sessitsch, A. Drought stress amelioration in wheat through inoculation with Burkholderia phytofirmans strain PsJN. Plant Growth Regulation 2014, 73, 121131, https://doi.org/10.1007/s10725-013-9874-8.

109. Naveed, M.; Mitter, B.; Reichenauer, T.G.; Wieczorek, K.; Sessitsch, A. Increased drought stress resilience of maize through endophytic colonization by Burkholderia phytofirmans PsJN and Enterobacter sp. FD17. Environmental and Experimental Botany 2014, 97, 30-39, https://doi.org/10.1016/j.envexpbot.2013.09.014.

110. Pinedo, I.; Ledger, T.; Greve, M.; Poupin, M.J. Burkholderia phytofirmans PsJN induces long-term metabolic and transcriptional changes involved in Arabidopsis thaliana salt tolerance. 2015, 6, https://doi.org/10.3389/fpls.2015.00466.

111. Fujishige, N.A.; Kapadia, N.N.; Hirsch, A.M. A feeling for the microorganism: structure on a small scale. Biofilms on plant roots. Botanical Journal of the Linnean Society 2006, 150, 79-88, https://doi.org/10.1111/j.1095-8339.2006.00492.x.

112. Rinaudi, L.V.; Giordano, W. An integrated view of biofilm formation in rhizobia. FEMS Microbiology Letters 2010, 304, 1-11, https://doi.org/10.1111/j.1574-6968.2009.01840.x.

113. Pangesti, N.; Pineda, A.; Pieterse, C.; Dicke, M.; Van Loon, J. Two-way plant mediated interactions between root-associated microbes and insects: from ecology to mechanisms. Frontiers in plant science 2013, 4, https://doi.org/10.3389/fpls.2013.00414.

114. Gutjahr, C. Phytohormone signaling in arbuscular mycorhiza development. Current Opinion in Plant Biology 2014, 20, 26-34, https://doi.org/10.1016/j.pbi.2014.04.003.

115. Kakoi, K.;Yamaura, M.; Kamiharai, T.; Tamari, D., Abe, M., Uchiumi, T., \& Kucho, K. I. Isolation of mutants of the nitrogen-fixing actinomycete Frankia. Microbes and environments 2013, 26, 31-37, https://doi.org/10.1264/jsme2.ME13126.

116. Field, K.J.; Pressel, S.; Duckett, J.G.; Rimington, W.R.; Bidartondo, M.I. Symbiotic options for the conquest of land. Trends in Ecology \& Evolution 2015, 30, 477-486, https://doi.org/10.1016/j.tree.2015.05.007.

117. Gourion, B.; Berrabah, F.; Ratet, P.; Stacey, G. Rhizobium-legume symbioses: the crucial role of plant immunity. Trends in plant science 2015, 20, 186-194, https://doi.org/10.1016/j.tplants.2014.11.008.

118. Koornneef, A.; Pieterse, C.M. Cross talk in defense signaling. Plant physiology 2008, 146, 839-844, https://doi.org/10.1104/pp.107.112029.

119. Yi, S.Y.; Shirasu, K.; Moon, J.S.; Lee, S.G.; Kwon, S.Y. The activated SA and JA signaling pathways have an influence on flg22-triggered oxidative burst and callose deposition. PloS one 2014, 9, https://doi.org/10.1371/journal.pone.0088951.

120. Boller, T.; Felix, G. A renaissance of elicitors: perception of microbe-associated molecular patterns and danger signals by pattern-recognition receptors. Annual review of plant biology 2009, 60, 379-406, https://doi.org/10.1146/annurev.arplant.57.032905.105346.

121. Allen, R.L.; Bittner-Eddy, P.D.; Grenville-Briggs, L.J.; Meitz, J.C.; Rehmany, A.P.; Rose, L.E.; Beynon, J.L. Host-Parasite Coevolutionary Conflict Between Arabidopsis and Downy Mildew. 2004, 306, 1957 1960, https://doi.org/10.1126/science.1104022.

122. Rivas, S.; Thomas, C.M. Molecular Interactions Between Tomato and the Leaf Mold Pathogen Cladosporium fulvum. Annual Review of Phytopathology 2005, 43, 395-436, https://doi.org/10.1146/annurev.phyto.43.040204.140224.

123. Tör, M.; Lotze, M.T.; Holton, N. Receptor-mediated signalling in plants: molecular patterns and programmes. Journal of experimental botany 2009, 60, 3645-3654,https://doi.org/10.1093/jxb/erp233.

124. Newman, M.A.; Sundelin, T.; Nielsen, J.T.; Erbs, G. MAMP (microbe-associated molecular pattern) triggered immunity in plants. Frontiers in plant science 2013, 4, https://doi.org/10.3389/fpls.2013.00139.

125. Fujita, M.; Fujita, Y.; Noutoshi, Y.; Takahashi, F.; Narusaka, Y.; Yamaguchi-Shinozaki, K.; Shinozaki, K. Crosstalk between abiotic and biotic stress responses: a current view from the points of convergence in the stress signaling networks. Current opinion in plant biology 2006, 9, 436-442, https://doi.org/10.1016/j.pbi.2006.05.014.

126. Hao, Y.; Charles, T.C.; Glick, B.R. ACC deaminase from plant growth-promoting bacteria affects crown gall development. Canadian Journal of Microbiology 2007, 53, 1291-1299, https://doi.org/10.1139/W07099.

127. Ali, S.; Charles, T.C.; Glick, B.R. Amelioration of high salinity stress damage by plant growth-promoting bacterial endophytes that contain ACC deaminase. Plant Physiology and Biochemistry 2014, 80, 160-167, https://doi.org/10.1016/j.plaphy.2014.04.003.

128. Glick, B.R. Bacteria with ACC deaminase can promote plant growth and help to feed the world. Microbiological research 2014, 169, 30-39, https://doi.org/10.1016/j.micres.2013.09.009. 
129. Sharma, A.; Shankhdhar, D.; Shankhdhar, S.C. Enhancing grain iron content of rice by the application of plant growth promoting rhizobacteria. Plant, Soil and Environment 2013, 59, 89-94, https://doi.org/10.17221/683/2012-PSE.

130. Sen, S.; Chandrasekhar, C.N. Effect of PGPR on growth promotion of rice (Oryza sativa L.) under salt stress. Asian J Plant Sci Res 2014, 4, 62-67.

131. Rojas-Tapias, D.; Moreno-Galván, A.; Pardo-Díaz, S.; Obando, M.; Rivera, D.; Bonilla, R. Effect of inoculation with plant growth-promoting bacteria (PGPB) on amelioration of saline stress in maize (Zea mays). Applied Soil Ecology 2012, 61, 264-272, https://doi.org/10.1016/j.apsoil.2012.01.006.

132. Suarez, C.; Cardinale, M.; Ratering, S.; Steffens, D.; Jung, S.; Montoya, A.M.Z.; Geissler-Plaum, R.; Schnell, S. Plant growth-promoting effects of Hartmannibacter diazotrophicus on summer barley (Hordeum vulgare L.) under salt stress. Applied Soil Ecology 2015, 95, 23-30, https://doi.org/10.1016/j.apsoil.2015.04.017.

133. Tien, T.M.; Gaskins, M.H.; Hubbell, D.H. Plant Growth Substances Produced by Azospirillum brasilense and Their Effect on the Growth of Pearl Millet (Pennisetum americanum L.). Appl Environ Microbiol 1979, 37, 1016-1024, https://doi.org/10.1128/aem.37.5.1016-1024.1979.

134. Williams, P.M.; De Mallorca, M.S. Abscisic acid and gibberellin-like substances in roots and root nodules ofGlycine max. Plant and Soil 1982, 65, 19-26, https://doi.org/10.1007/BF02376799.

135. Badenoch-Jones, J.; Letham, D.S.; Parker, C.W.; Rolfe, B.G. Quantitation of Cytokinins in Biological Samples Using Antibodies Against Zeatin Riboside. Plant Physiology 1984, 75, 1117-1125, https://doi.org/10.1104/pp.75.4.1117.

136. Taller, B.J.; Wong, T.Y. Cytokinins in Azotobacter vinelandii culture medium. Applied and environmental microbiology, 1989, 55, 266-267.

137. Nieto, K.F.; Frankenberger, W.T. Biosynthesis of cytokinins by Azotobacter chroococcum. Soil Biology and Biochemistry 1989, 21, 967-972, https://doi.org/10.1016/0038-0717(89)90089-8.

138. Patten, C.L.; Glick, B.R. Role of \&lt;em\&gt;Pseudomonas putida\&lt;/em\&gt; Indoleacetic Acid in Development of the Host Plant Root System. Applied and Environmental Microbiology 2002, 68, 37953801, https://doi.org/10.1128/AEM.68.8.3795-3801.2002.

139. Glick, B.R. Plant growth-promoting bacteria: mechanisms and applications. Scientifica 2012, 2012, https://doi.org/10.6064/2012/963401.

140. Rajkumar, M.; Ma, Y.; Freitas, H. Improvement of Ni phytostabilization by inoculation of Ni resistant Bacillus megaterium SR28C. Journal of environmental management 2013, 128, 973-980, https://doi.org/10.1016/j.jenvman.2013.07.001.

141. Ahmed, A.; Hasnain, S. Auxins as one of the factors of plant growth improvement by plant growth promoting rhizobacteria. Pol. J. Microbiol 2014, 63, 261-266, https://doi.org/10.33073/pjm-2014-035.

142. Fierro-Coronado, R.A.; Quiroz-Figueroa, F.R.; García-Pérez, L.M.; Ramírez-Chávez, E.; Molina-Torres, J.; Maldonado-Mendoza, I.E. IAA-producing rhizobacteria from chickpea (Cicer arietinum L.) induce changes in root architecture and increase root biomass. Canadian journal of microbiology 2014, 60, 639-648, https://doi.org/10.1139/cjm-2014-0399.

143. Etesami, H.; Mirseyed Hosseini, H.; Alikhani, H.A. Bacterial biosynthesis of 1-aminocyclopropane-1caboxylate (ACC) deaminase, a useful trait to elongation and endophytic colonization of the roots of rice under constant flooded conditions. Physiology and Molecular Biology of Plants 2014, 20, 425-434, https://doi.org/10.1007/s12298-014-0251-5.

144. Khan, A.L.; Waqas, M.; Kang, S.-M.; Al-Harrasi, A.; Hussain, J.; Al-Rawahi, A.; Al-Khiziri, S.; Ullah, I.; Ali, L.; Jung, H.-Y.; Lee, I.-J. Bacterial endophyte Sphingomonas sp. LK11 produces gibberellins and IAA and promotes tomato plant growth. Journal of Microbiology 2014, 52, 689-695, https://doi.org/10.1007/s12275-014-4002-7.

145. Kudoyarova, G.R.; Melentiev, A.I.; Martynenko, E.V.; Timergalina, L.N.; Arkhipova, T.N.; Shendel, G.V.; Kuz' mina, L.Y.; Dodd, I.C.; Veselov, S.Y. Cytokinin producing bacteria stimulate amino acid deposition by wheat roots. Plant Physiology and Biochemistry 2014, 83, 285-291, https://doi.org/10.1016/j.plaphy.2014.08.015.

146. Penrose, D.M.; Glick, B.R. Methods for isolating and characterizing ACC deaminase-containing plant growth-promoting rhizobacteria. Physiologia Plantarum 2003, 118, 10-15, https://doi.org/10.1034/j.13993054.2003.00086.x.

147. Glick, B.R.; Todorovic, B.; Czarny, J.; Cheng, Z.; Duan, J.; McConkey, B. Promotion of Plant Growth by Bacterial ACC Deaminase. Critical Reviews in Plant Sciences 2007, 26, 227-242, https://doi.org/10.1080/07352680701572966.

148. Sessitsch, A.; Coenye, T.; Sturz, A.V.; Vandamme, P.; Barka, E.A.; Salles, J.F.; Van Elsas, J.D.; Faure, D.; Reiter, B.; Glick, B.R.; Wang-Pruski, G.; Nowak, J. Burkholderia phytofirmans sp. nov., a novel plantassociated bacterium with plant-beneficial properties. 2005, 55, 1187-1192, https://doi.org/10.1099/ijs.0.63149-0.

149. Sun, Y.; Cheng, Z.; Glick, B.R. The presence of a 1-aminocyclopropane-1-carboxylate (ACC) deaminase deletion mutation alters the physiology of the endophytic plant growth-promoting bacterium Burkholderia 
phytofirmans PsJN. FEMS Microbiology Letters 2009, 296, 131-136, https://doi.org/10.1111/j.15746968.2009.01625.x.

150. Stearns, J.C.; Glick, B.R. Transgenic plants with altered ethylene biosynthesis or perception. Biotechnology Advances 2003, 21, 193-210, https://doi.org/10.1016/S0734-9750(03)00024-7.

151. Lim, J.-H.; Kim, S.-D. Induction of Drought Stress Resistance by Multi-Functional PGPR Bacillus licheniformis K11 in Pepper. The Plant Pathology Journal 2013, 29, 201-208, https://doi.org/10.5423\%2FPPJ.SI.02.2013.0021.

152. Hallmann, J.; Quadt-Hallmann, A.; Mahaffee, W.F.; Kloepper, J.W. Bacterial endophytes in agricultural crops. Canadian journal of microbiology 1997, 43, 895-914, https://doi.org/10.1139/m97-131.

153. Reiter, B.; Sessitsch, A. Bacterial endophytes of the wildflower Crocus albiflorus analyzed by characterization of isolates and by a cultivation-independent approach. Canadian journal of microbiology 2006, 52, 140-149, https://doi.org/10.1139/w05-109.

154. Farrell, M.; Prendergast-Miller, M.; Jones, D.L.; Hill, P.W.; Condron, L.M. Soil microbial organic nitrogen uptake is regulated by carbon availability. Soil Biology and Biochemistry 2014, 77, 261-267, https://doi.org/10.1016/j.soilbio.2014.07.003.

155. Reinhold-Hurek, B.; Hurek, T. Life in grasses: diazotrophic endophytes. Trends in Microbiology 1998, 6, 139-144, https://doi.org/10.1016/S0966-842X(98)01229-3.

156. James, E.K. Nitrogen fixation in endophytic and associative symbiosis. Field Crops Research 2000, 65, 197 209, https://doi.org/10.1016/S0378-4290(99)00087-8.

157. Baldotto, L.E.B.; Olivares, F.L.; Bressan-Smith, R. Structural interaction between GFP-labeled diazotrophic endophytic bacterium Herbaspirillum seropedicae RAM10 and pineapple plantlets' Vitória'. Brazilian Journal of Microbiology 2011, 42, 114-125, https://doi.org/10.1590/S1517-83822011000100015.

158. Huang, B.; Lv, C.; Zhuang, P.; Zhang, H.; Fan, L. Endophytic colonisation of Bacillus subtilis in the roots of Robinia pseudoacacia L. Plant Biology 2011, 13, 925-931, https://doi.org/10.1111/j.14388677.2011.00456.x.

159. Prieto, P.; Schilirò, E.; Maldonado-González, M.M.; Valderrama, R.; Barroso-Albarracín, J.B.; MercadoBlanco, J. Root Hairs Play a Key Role in the Endophytic Colonization of Olive Roots by Pseudomonas spp. with Biocontrol Activity. Microbial Ecology 2011, 62, 435-445, https://doi.org/10.1007/s00248-011-98276.

160. Danhorn, T.; Fuqua, C. Biofilm formation by plant-associated bacteria. Annu. Rev. Microbiol. 2007, 61, 401422, https://doi.org/10.1146/annurev.micro.61.080706.093316.

161. Hornschuh, M.; Grotha, R.; Kutschera, U. Moss-associated methylobacteria as phytosymbionts: an experimental study. Naturwissenschaften 2006, 93, 480-486, https://doi.org/10.1007/s00114-006-0137-7.

162. Jacquemyn, H.; Waud, M.; Merckx, V.S.F.T.; Lievens, B.; Brys, R. Mycorrhizal diversity, seed germination and long-term changes in population size across nine populations of the terrestrial orchid Neottia ovata. Molecular Ecology 2015, 24, 3269-3280, https://doi.org/10.1111/mec.13236.

163. Bragina, A.; Berg, C.; Cardinale, M.; Shcherbakov, A.; Chebotar, V.; Berg, G. Sphagnum mosses harbour highly specific bacterial diversity during their whole lifecycle. The ISME Journal 2012, 6, 802-813, https://doi.org/10.1038/ismej.2011.151.

164. Alavi, P.; Starcher, M.; Zachow, C.; Müller, H.; Berg, G. Root-microbe systems: the effect and mode of interaction of stress protecting agent (SPA) Stenotrophomonas rhizophila DSM14405T. Frontiers in Plant Science 2013, 4, https://doi.org/10.3389/fpls.2013.00141.

165. Tkacz, A.; Poole, P. Role of root microbiota in plant productivity. Journal of experimental botany 2015, 66, 2167-2175, https://doi.org/10.1093/jxb/erv157.

166. Weller, D.M.; Raaijmakers, J.M.; Gardener, B.B.M.; Thomashow, L.S. Microbial populations responsible for specific soil suppressiveness to plant pathogens. Annual review of phytopathology 2002, 40, 309-348, https://doi.org/10.1146/annurev.phyto.40.030402.110010.

167. Lugtenberg, B.; Kamilova, F. Plant-growth-promoting rhizobacteria. Annual review of microbiology 2009, 63, 541-556, https://doi.org/10.1146/annurev.micro.62.081307.162918.

168. Bragina, A.; Cardinale, M.; Berg, C.; Berg, G. Vertical transmission explains the specific Burkholderia pattern in Sphagnum mosses at multi-geographic scale. Frontiers in microbiology 2013, 4, https://doi.org/10.3389/fmicb.2013.00394.

169. Yang, J.; Kloepper, J.W.; Ryu, C.-M. Rhizosphere bacteria help plants tolerate abiotic stress. Trends in Plant Science 2009, 14, 1-4, https://doi.org/10.1016/j.tplants.2008.

170. Rolli, E.; Marasco, R.; Vigani, G.; Ettoumi, B.; Mapelli, F.; Deangelis, M. L.; Pierotti Cei, F. Improved plant resistance to drought is promoted by the root-associated microbiome as a water stress-dependent trait. Environmental microbiology 2015, 17, 316-331, https://doi.org/10.1111/1462-2920.12439.

171. Zabetakis, I.; Moutevelis-Minakakis, P.; Gramshaw, J.W. The role of 2-hydroxypropanal in the biosynthesis of 2,5-dimethyl-4-hydroxy-2H-furan-3-one in strawberry (Fragaria $\times$ ananassa, cv. Elsanta) callus cultures. Food Chemistry 1999, 64, 311-314, https://doi.org/10.1016/S0308-8146(98)00105-8.

172. Verginer, M.; Siegmund, B.; Cardinale, M.; Müller, H.; Choi, Y.; Míguez, C.B.; Leitner, E.; Berg, G. Monitoring the plant epiphyte Methylobacterium extorquens DSM 21961 by real-time PCR and its influence 
on the strawberry flavor. FEMS microbiology ecology 2010, 74, 136-145, https://doi.org/10.1111/j.15746941.2010.00942.x.

173. Badri, D.V.; Zolla, G.; Bakker, M.G.; Manter, D.K.; Vivanco, J.M. Potential impact of soil microbiomes on the leaf metabolome and on herbivore feeding behavior. New Phytologist 2013, 198, 264-273, https://doi.org/10.1111/nph.12124.

174. Peñuelas, J.; Farré-Armengol, G.; Llusia, J.; Gargallo-Garriga, A.; Rico, L.; Sardans, J.; Terradas, J.; Filella, I. Removal of floral microbiota reduces floral terpene emissions. Scientific Reports 2014, 4, https://doi.org/10.1038/srep06727.

175. Wagner, M.R.; Lundberg, D.S.; Coleman-Derr, D.; Tringe, S.G.; Dangl, J.L.; Mitchell-Olds, T. Natural soil microbes alter flowering phenology and the intensity of selection on flowering time in a wild Arabidopsis relative. Ecology Letters 2014, 17, 717-726, https://doi.org/10.1111/ele.12276.

176. Panke-Buisse, K.; Poole, A.C.; Goodrich, J.K.; Ley, R.E.; Kao-Kniffin, J. Selection on soil microbiomes reveals reproducible impacts on plant function. The ISME Journal 2015, 9, 980-989, https://doi.org/10.1038/ismej.2014.196.

177. Partida-Martinez, L.P.P.; Heil, M. The microbe-free plant: fact or artifact?. Frontiers in plant science 2011, 2, https://doi.org/10.3389/fpls.2011.00100.

178. Germida, J.; Siciliano, S. Taxonomic diversity of bacteria associated with the roots of modern, recent and ancient wheat cultivars. Biology and Fertility of Soils 2001, 33, 410-415, https://doi.org/10.1007/s003740100343.

179. Berg, G.; Grube, M.; Schloter, M.; Smalla, K. The plant microbiome and its importance for plant and human health. Frontiers in Microbiology, 2014, 5, 1. https://doi.org/10.3389/fmicb.2014.00491

180. Cardinale, M.; Grube, M.; Erlacher, A.; Quehenberger, J.; Berg, G. Bacterial networks and co-occurrence relationships in the lettuce root microbiota. Environmental microbiology, 2015, 17, (1), 239252.https://doi.org/10.1111/1462-2920.12686. 